\title{
On the corruption trail
}

Once seeking to be a biochemist, Dominic Kakas decided to commit himself to journalism. Fired by a strong desire to make a difference with Papua New Guinea's growing corruption problem, he is now editor of The Independent.

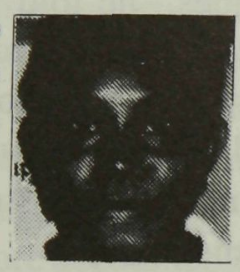

\section{By LYNNE AMEPOU}

DOMINIC KAKAS once wanted to be a scientist - in particular, a biochemist. But fate had other plans for him. Today, at 28, he is editor of The Independent, a weekly in-depth newspaper published by Word Publishing in Papua New Guinea.

Born in July 1968 in Enga province to Joseph and Maria Kakas, he is the second-born in a family of four sisters and one brother. Kakas spent the first three years of his life in his home province but, because his father was a policeman, the Kakas family moved around a lot. Finally the family settled in Port Moresby where Kakas grew up and went to school.

Dominic Kakas attended Saint Peter's Primary School at Erima from 1975 to 1980 . After completing year six, he was selected to go to De La Salle High School, Bomana, on the outskirts of Port Moresby. He stayed there for two years, from 1981 to 1984.

In 1985, he went to Passam National High School in Wewak to do grades 11 and 12. But throughout his school years he only had one thought — to fulfill his dream of becoming a scientist. At Passam, he majored in science, taking physics, chemistry, biology and major maths.

Towards the end of 1986, when the time came to fill in his school leaver form, Kakas found that although he did well in the science courses, his maths grades were not good enough to apply for the science foundation course at the University of Papua New Guinea. That came as a big blow; his dream was shattered. However, he had good marks in English, and although he didn't 
realise it then, he had a gift for words.

His guidance teacher encouraged him to apply for a journalism course. Kakas took his advice and applied, 'rather halfheartedly', he recalls. 'I'll just do this and see how it goes,' he told himself. In 1987, he was accepted and started a Diploma in Media Studies course, thinking he would stream to science later.

After completing the two years required for a diploma, he decided to stay on and complete a Bachelor in Journalism degree course which would take a further two years. In those

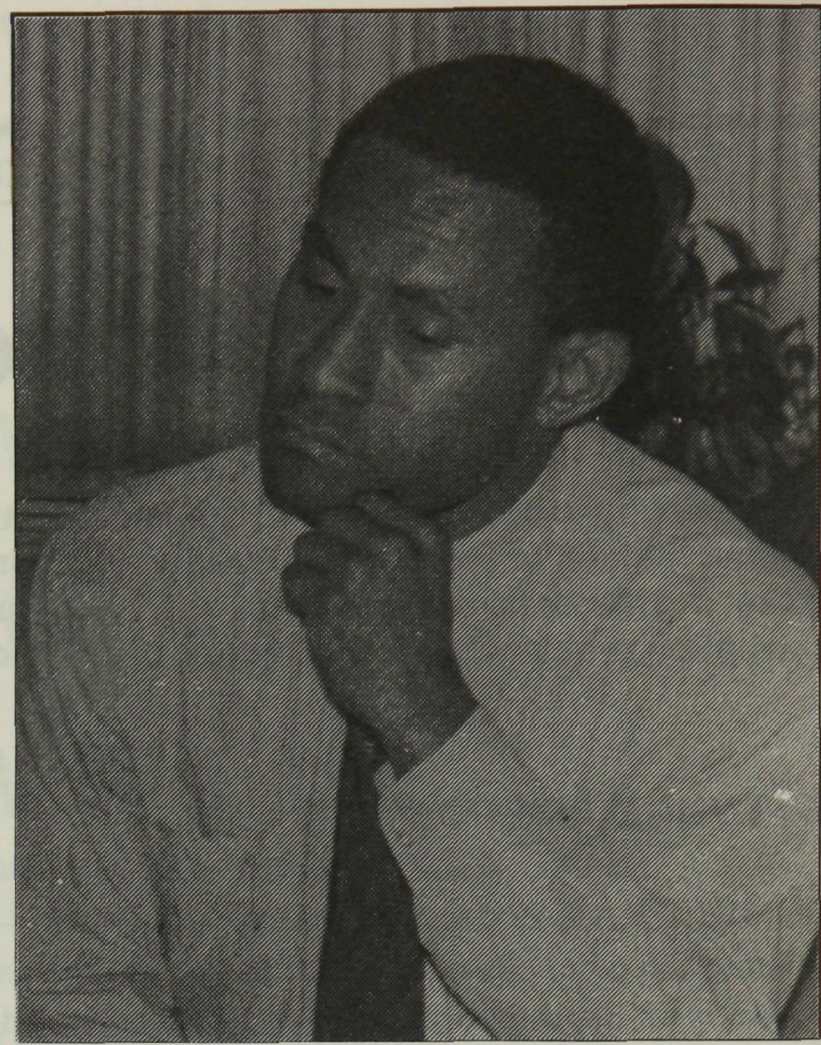

Kakas ... 'I made up my mind'. two years, one of the topics taught was 'Ethics of Development'. This especially appealed to Kakas because it offered an insight into Papua New Guinea's development and where the country was heading. It was in one of these lessons that Kakas finally accepted what fate had in store for him.

'I sat in that class and made up my mind to be a mirror, a spotlight to expose corruption,' he said. 'If it meant being a journalist to do so, then I would become one.'

From then on, all thoughts of being a biochemist faded and committed himself to journalism. Fired by a strong desire to make a difference with Papua New Guinea's growing corruption problem, Kakas put all his effort into the task at hand - getting through school.

He graduated in 1990 and in November started work as a cadet reporter for Word Publishing, at that time with The Times of Papua New Guinea. However, he left in January 1994 and joined the Investment Promotion Authority as a public relations officer. He left The Times because he needed a "change of scenery'. However, he missed being a journalist and in May 1995 he was back with Word Publishing, this time as editor of The Independent.

Often his news stories are carried on the front page of the paper. And in May 
1996 he was commended in the inaugural Pacific Investigative Journalism Award for his front page story about a house for Forests Minister Andrew Posai being paid for by a major logging company. Posai was forced out of office in disgrace.

Kakas attributes his success in journalism to the two lecturers who taught him at the university - Peter Henshall and David Ingram: 'They always had time to talk to individuals no matter if it was after hours.' He also draws inspiration from Paul Cox, best known as the columnist 'Pinder', whose work Kakas admires very much.

Kakas believes one of the stumbling blocks for investigative reporting is that although there is a lot of information about corruption, it is difficult to get hard facts. Another thing is establishing contacts and winning their trust. His advice to young journalists is: 'Steer clear of politics." He regards journalism as a noble career and says journalists should uphold their ethics.

However, he does not believe the media should be made more accountable - certainly not to politicians. He strongly feels that the media is accountable enough as it is. People seeking redress have the courts to go to. The PNG Media Council is another body to which they can take their grievences. The media should be free to report because only then will corruption be revealed.

When not chasing stories, Kakas is out playing rugby league with his mates for the Souths club in Port Moresby. He is a big fan of the Parramatta Eels. Other than that, journalism is his full time occupation. When asked if he had any memorable experiences, he said with a chuckle: 'I' $m$ a very superstious person so I won't answer that. If I do my luck might run out.'

$\square$ Lynne Amepou is a first-year journalism student at the University of PNG. She wrote this article as a practical reporting assignment. 